DOI: 10.46340/eppd.2020.7.6.47

Mykhailo Borusovskiy

ORCID ID: https://orcid.org/0000-0002-8269-627X

Lviv State University of Internal Affairs, Ukraine

\title{
THE TACTICS OF INTERROGATION OF WITNESSES DURING THE INVESTIGATION OF ABUSE OF AUTHORITY OR OFFICIAL POSITION BY A JUDGE DURING A JUDGMENT
}

\author{
Михайло Борусовський \\ Львівський державний університет внутрішніх справ, Україна \\ ТАКТИКА ДОПИТУ СВІДКІВ ПІД ЧАС \\ РОЗСЛІУВАННЯ ЗЛОВЖИВАННЯ ВЛАДОЮ \\ АБО СЛУЖБОВИМ СТАНОВИЩЕМ СУДДЕЮ \\ ПІД ЧАС ЗДІСНЕННЯ ПРАВОСУДДЯ
}

\begin{abstract}
The scientific article is devoted to the issue of procedural regulations and tactics of interrogation of witnesses during the investigation of abuse of power or official position by a judge during a judgement. Witnesses of abuse of power or official position by a judge during a judgement are divided into six categories taking into account their procedural position. Typical questions for each of the categories of witnesses have been developed. The need is emphasized to interrogate individuals with the use of security measures, or using the possibility of interrogation by an investigating judge during the pre-trial investigation, provided for in Art. 225 of the Criminal Procedursl Code of Ukraine. Certain legislative changes have been proposed regarding the criminal procedural regulation of the interrogation of a judge or juror as a witness of abuse of authoruty or official position by a judge (juror) during the judgement.
\end{abstract}

Keywords: investigation; criminal proceedings; sentence; decision; approval; decree; interrogation; witness.

Постановка проблеми. Важливим джерелом здобуття доказів у кримінальних провадженнях про зловживання владою або службовим становищем суддею під час здійснення правосуддя, $€$ показання свідків, корті отримують в ході проведення допиту свідків, проведення якого має свої особливості. Тому, метою статті $є$ розкрити тактику допиту свідків під час розслідування зловживання владою або службовим становищем суддею під час здійснення правосуддя.

Стан дослідження. Проблема проведення допиту та удосконалення його процесуальних, організаційних, тактичних аспектів розроблялися у працях Ю.П. Аленіна, Р.С. Бєлкіна, В.В. Весельського, В.І. Галагана, В.О. Коновалової, В.С. Кузьмичова, М.М. Михеєнка, М.І. Порубова, С.М. Стахівського, В.В. Тертишника, П.В. Цимбала, В.Ю. Шепітька, С.А. Шейфера та інших вчених. Проте праці зазначених вчених стосуються в переважній більшості загальним потопленням криміналістичної тактики допиту. Метою нашого дослідження $\epsilon$ розроблення тактичних особливостей допиту свідків під час розслідування зловживання владою або службовим становищем суддею під час здійснення правосуддя.

Виклад основних положень. Слід почати 3 того, що до структури окремої методики розслідування злочинів усфері службової діяльності входять такі елементи: криміналістична характеристика злочинів у сфері службової діяльності; збирання та перевірка первинної інформації про правопорушення у сфері службової діяльності; початковий етап розслідування; наступний етап розслідування; особливості проведення слідчих (розшукових) і негласних слідчих (розшукових) дій; особливості подолання протидії розслідуванню злочинів у сфері службової діяльності ${ }^{1}$. Не $\epsilon$ винятком

\footnotetext{
${ }^{1}$ Пчеліна, О. В. (2017). Теоретичні засади формування та реалізації методики розслідування злочинів у сфері службової діяльності: автореферат дисертації на здобуття наукового ступеню доктора юридичних наук. Харків, 31.
} 
формування основ методики розслідування зловживання владою або службовим становищем суддею під час здійснення правосуддя, під час якої важливе місце відводиться тактиці допиту свідків.

Як справедливо аргументує О. Л. Мусієнко, значний обсяг інформації, що має значення для швидкого й ефективного розслідування, органи розслідування одержують саме від свідків. Значущість повідомлюваних свідками відомостей залежить від низки чинників, серед яких переважає бажання, продиктоване обов'язками громадянина припинити злочинну діяльність певних осіб. Саме ця обставина спричиняє важливість визначення груп свідків, їхньої спрямованості, потенційних можливостей для одержання даних, що сприяють розслідуванню злочинів. Повідомлювана свідками інформація в загальному вигляді залежить від ступенів поінформованості останніх, однак у більш докладній градації й від інших характеристик ${ }^{2}$.

Згідно з ч.1 ст.65 КПК України свідком є фізична особа, якій відомі або можуть бути відомі обставини, що підлягають доказуванню під час кримінального провадження, i яка викликана для давання показань. Процесуальний порядок допиту свідків під час досудового розслідування регламентований ст.ст. 224-227 КПК України та не може проводитися у нічний час (3 22 до 6 год.), тривати понад 8 годин, із обов'язковою перервою у випадку його проведення понад 2 години.

Допит свідків, в ході розслідування кримінального провадження про зловживання владою або службовим становищем суддею під час здійснення правосуддя слід проводити згідно загальних умов криміналістичної тактики допиту. Під час такого, необхідною умовою успішного проведення такого роду допиту є підготовка до нього, яка охоплює ряд конкретних заходів, серед яких слід виділити: вивчення матеріалів кримінального провадження, ознайомлення з даними про особу допитуваного, а також складання плану допиту. Так, перед допитом встановлюють особу свідка, повідомляють його у якому кримінальному провадженні він викликаний, попереджають про обов'язок розповісти все відоме йому про подію чи певних осіб, а також про кримінальну відповідальність за відмову дати показання та за дачу завідомо неправдивих показань (ст.ст. 384, 385 КК України). Слідчий з'ясовує його стосунки з підозрюваним та потерпілим, роз'яснює право не давати показань щодо себе, членів сім’'і, близьких родичів (ч. 1 ст. 63 Конституції України). Після вільної розповіді свідок відповідає на запитання слідчого. Запитання треба ставити у певній послідовності. Це дасть змогу отримати необхідну інформацію, витрачаючи менше часу і сил. При формулюванні запитання слід враховувати культурний рівень особи та їі обізнаність з нормативно-правовими актами. Законодавець заборонив під час будь-якого прямого допиту, зокрема під час досудового розслідування, ставити навідні запитання, тобто запитання, у формулюванні яких міститься відповідь, частина відповіді або підказка до неї (ч.6 ст. 352 КПК України).

Свідків постановлення суддею (суддями) завідомо неправосудного вироку, рішення, ухвали або постанови можна поділити на такі категорії:

1. Особи, які були брали участь у судовому розгляді $i$ безпосередньо сприймали факт здійснення правосуддя;

2. Особи, які не брали участі у судовому розгляді, проте яким відомі факти зловживання владою або службовим становищем суддею під час здійснення правосуддя;

3. Особи, які встановили факти зловживання владою або службовим становищем суддею під час здійснення правосуддя;

4. Особи, які є працівниками апарату суду та можуть підтвердити приналежність чи можуть охарактеризувати особу злочиния;

5. Особи або працівники правоохоронного органу, які проводили оперативно-розщукові заходи або негласні слідчі (розщукові) дії, зметою документування факту зловживання владою або службовим становищем суддею під час здійснення правосуддя;

6. Особи, що залучалися до проведення процесуальних дій в рамках судового розгляду (поняті, працівники правоохоронних органів, спеціалісти, експерти тощо).

Перша категорія свідків для нас має найбільше значення, оскільки саме їхні показання в деяких випадках можуть слугувати найбільш ефективним джерелом доказів у даній категорії кримінальних проваджень. До цієї категорії можна віднести свідків, які були присутніми під час судового розгляду, де було прийнято судове рішення. Запитання, які можна поставити до категорії таких свідків:

1) Коли і при яких обставинах та в якому складі суду відбувався судовий розгляд? Чи здійснювалося фіксування судового розгляду?

\footnotetext{
${ }^{1}$ Мусієнко, О. Л. (2007). Теоретичні засади розслідування шахрайства в сучасних умовах: дисертація на здобуття наукового ступеню кандидата юридичних наук. Харків, 122.
} 
2) В якому процесуальному статусі Ви брали участь в судовому засіданні?

3) Яким чином здійснювався Ваш виклик?

4) Чи знайомі Ви з потерпілим (підозрюваним)?

5) Прошу розповісти про обставини судового розгляду?

3) Чи відомо Вам про факти будь-якого конфлікту між підозрюваним та потерпілим?

4) Чи відомі Вам факти заявлення відводу судді (суддям)?

4) Якими були дії потерпілого?

5) Якими були дії підозрюваного?

Також до цієї категорії можна віднести суддів, у разі колегіального розгляду справи, які винесли окрему думку, а також присяжних, у разі їхньої участі у судовому розгляді.

Особливістю допиту свідків, якими під час досудового розслідування досліджуваного нами виду кримінального правопорушення, можуть бути судді чи присяжні є те, що їх не можна допитувати в якості свідка - про обставини обговорення в нарадчій кімнаті питань, що виникли під час ухвалення судового рішення. Проте, власне таким винятком $€$ кримінальне провадження щодо прийняття суддею (суддями) завідомо неправосудного вироку, ухвали (п. 7 ч. 2 ст. 65 КПК України). На нашу думку, у зв'язку із прийняттям рішення Конституційним судом про неконституційність ст. 375 КК України, що передбачає кримінальну відповідальність за постановлення суддею завідомо неправосудного рішення, вироку, ухвали, постанови, законодавцеві слід внести відповідні зміни до п. 7 ч. 2 ст. 65 КПК України та викласти іiі у наступній редакції: «судді та присяжні - про обставини обговорення в нарадчій кімнаті питань, що виникли під час ухвалення судового рішення, за винятком випадків кримінального провадження щодо зловживання владою або службовим становищем суддею (присяжним) під час прийняття судового рішення».

Другу категорію свідків представляють особи, яким будь яким чином відомі факти зловживання владою або службовим становищем суддею під час прийняття судового рішення, або $\epsilon$ представниками ЗМІ, що провадять власне журналістське розслідування. У разі, якщо свідком $\epsilon$ журналіст, то отримати показання від нього можливо за його добровільною згодою. Без такої згоди, він не може бути допитаний щодо відомостей, які містять конфіденційну інформацію професійного характеру, надану за умови нерозголошення авторства або джерела інформації (п. 6 ч. 2 ст. 65 КПК Країни). Типові запитання до цієї категорії свідків:

1) Що Вам відомо з приводу здійснення правосуддя?

2) Чи відомо Вам факт зловживання владою або службовим становищем суддею (присяжним) під час прийняття судового рішення ? Якщо так, то звідки Ви дізналися про це?

3) Чи зверталися Ви в правоохоронні органи з даного приводу?

Третя категорія свідків, пов'язана із службовими особами, які за допомогою своїх спеціальних правових знань встановлюють зловживання владою або службовим становищем суддею під час прийняття судового рішення. До цієї категорії відносимо суддів, що здійснювали перегляд судового рішення у апеляційній чи касаційній інстанції, та представників Вищої ради правосуддя (далі - ВРП). Типові запитання слідчого до третьої категорії свідків:

1. Якщо свідками є представники ВРП:

1) Хто звернувся зі скаргою до ВРП? Які обставини викладені у скарзі?

2) Чи були виявлені порушення під час судового розгляду? Чи містить судове рішення ознаки порушення правової процедури чи кваліфікації? Якщо так, то в чому вони полягають? Які порушення у прийнятому судовому рішенні були виявлені?

3) Яким був розгляд та яке рішення прийнято членами ВРП?

4) Чи ініціювалося питання про відсторонення судді від здійснення правосуддя? Якщо так, то яким був результат?

2. Якщо свідками є судді, що здійснювали перегляд судового рішення:

1) Хто звернувся із апеляційною (касаційною) скаргою. Яким був перегляд судового рішення, чи були встановлені обставини неправосудності чи зловживання владою або службовими повноваженнями суддею під час здійснення правосуддя? Якщо так, то які саме? Яке рішення було винесене за наслідками розгляду скарги?

До свідків четвертої категорії можуть відноситися секретар судового засідання, помічник судді, судовий розпорядник, голова апарату суду тощо.

Запитання до даної категорії свідків полягають в основному у їх участі у судовому розгляді справи та характеристиці підозрюваного (их). Типовими запитаннями є:

1) Чи брали Ви участь у судовому розгляді конкретної судової справи? Якщо так, то в якому статусі та якими були Ваші функції? 
2) Чи відбувалося фіксування судового розгляду? Якщо так, то яким чином?

3) Хто був присутнім під час судового розгляду?

4) Яке рішення було прийнято за результатами судового розгляду? Хто та яким чином з ним ознайомився?

5) Чи відомо Вам, чи хтось відвідував суддю (ів) перед початком судового розгляду? Якщо так, то чи відомо Вам з приводу чого?

6) Чи відомі Вам факти зловживання владою або службовим становищем під час здійснення правосуддя? Якщо так, то чим Ви їх обгрунтовуєте? Чи повідомляли про цей факт когось?

7) Чи давав будь яке розпорядження суддя (судді), з приводу підготовки тексту судового рішення?

П'яту категорію свідків представляють особи - конфіденти або працівники правоохоронних органів. Окремих осіб з цієї категорії, на нашу думку допитувати із застосуванням заходів безпеки, або з використанням можливості допиту слідчим суддею під час досудового розслідування, що передбачений ст. 225 КПК України.

Остання класифікаційна категорія свідків у кримінальному провадженні про зловживання владою або службовим становищем суддею під час прийняття судового рішення, відіграє для процесу доказування допоміжну функцію. Зокрема, віднесені до цієї групи особи, унаслідок виконання своїх службових функцій чи громадського обов'язку під час допиту можуть засвідчити перебіг процесуальної дії під час судового розгляду, поведінку іiі учасників та інші особливості. Типові запитання до зазначеної категорії свідків:

1). Хто, коли та до якої саме процесуальної дії дії Вас залучав? Яким був склад суду?

2). Що Вам стало відомо під час проведення процесуальної, до якої Вас було залучено?

3). Яким був перебіг процесуальної дії та якою була поведінка ії учасників?

Загалом слід зауважити, що такий поділ є доволі умовним і на практиці може виникнути ситуації, де свідками можуть бути інші особи. Проте, загалом слід відзначити, що слідчому слід використовувати усі можливі тактичні прийоми, з метою отримання позитивного результату в ході допиту.

У такому випадку I. Кертес стверджує, що основні мотиви, ставлення допитуваного до завдання, поставленого перед ним, характеризуються позитивно чи негативно. Залежно від позитивного або негативного вирішення питання ми й говоримо про сумлінного або несумлінного допитуваного. Такий поділ має, звичайно, умовний характер в тому розумінні, що загальна характеристика сумлінності або несумлінності не завжди визначає ставлення допитуваного рівною мірою до всіх питань, що задаються слідчим, і що недобросовісний допитуваний під впливом правильної тактики допиту може перетворюватися на сумлінного або, навпаки, сумлінний допитуваний під впливом різних факторів, зокрема неправильної тактики ведення допиту, перетворюється іноді в недобросовісного. Питання ускладнюється ще тим, що мотиви допитуваного часто суперечать один одному, між ними триває боротьба, у яку повинен втручатися слідчий, забезпечуючи перемогу саме тих із них, які спонукають допитуваного говорити правду. Слідчий повинен і до, і під час допиту вивчати особистість допитуваного, його світогляд, інтереси, мотиви, якими він керується на допиті. Мотиви його поведінки виявляються шляхом аналізу особистості допитуваного, його поведінки на допиті, взаємин з іншими учасниками процесу, ставлення до факту злочину, зіставлення його показань з іншими доказами, а також різних частин показань цієї особи або iї показань, наданих у різний час ${ }^{1}$.

На думку відомого криміналіста Ганса Гроса: «Свідок невмілому слідчому або нічого не розповість, або розкаже несуттєве, або зовсім невірне, і той же свідок дасть досить правдиві, точні і докладні свідчення тому слідчому, який зуміє заглянути в його душу, зрозуміти його і зуміти з ним зійтись» ${ }^{2}$. Тому під час проведення різного типу допитів важливим $є$ використання тактичних прийомів. Власне вибір тактичних прийомів суттєво залежить від особливостей ситуації, що складається при допиті. Сукупність цих особливостей завжди унікальна, неповторна та накладає свій відбиток на подальший хід досудового розслідування.

Тактичні прийоми проведення допиту залежать від ситуації, що складається на допиті, та характеру отримуваної інформації. Слід погодитися з В. О. Коноваловою, яка запропонувала тактичні

\footnotetext{
${ }^{1}$ Кертэс, И. (1965). Тактика и психологические основы допроса. Москва: Юридическая литература, $150-153$.

${ }^{2}$ Гросс Г. (1930). Руководство для судебных следователей как система криминалистики. Москва:

Издательство Народного комиссариата внутренних дел РСФСР, 45-46.
} 
прийоми допиту свідків поділити на такі групи: прийоми актуалізації зображеного свідком; прийоми, що сприяють відтворенню (словесному) відомої свідкові події; прийоми, спрямовані на викриття брехні й установлення мотивів замовчування в показаннях свідка; прийоми, спрямовані на встановлення помилок у свідченнях та їх усунення ${ }^{1}$. Уміле застосування зазначених тактичних прийомів допоможе слідчому одержати потрібну інформацію й не продемонструвати обсяг своєї поінформованості.

Найчастіше свідкам пропонується спочатку розповісти все, що їм відомо про злочин. Після вільної розповіді слідчий ставить потрібні запитання. У разі, якщо свідок дає неправдиві показання, або замовчує деякі обставини вчинення зловживання владою або службовим становищем суддею під час прийняття судового рішення, слідчому доцільно застосовувати такі тактичні прийоми, як постановка запитань, що деталізують і контролюють допит по епізодах; оголошення показань інших осіб; пред'явлення речових доказів тощо.

Запропоновані блоки запитань, які з'ясовуються при допиті тієї чи іншої категорії свідків, мають орієнтовний характер і підлягають індивідуальному корегуванню залежно від ситуації, що склалась.

Таким чином, ми розглянули питання процесуальної регламентації та тактики допиту свідків під час розслідування зловживання владою або службовим становищем суддею під час здійснення правосуддя. В ході дослідження, свідків поділено на шість категорій, розроблено типові питання до кожної із них, запропоновано певні законодавчі зміни щодо кримінальної процесуальної регламентації допиту судді, в якості свідка зловживання владою або службовим становищем суддею (присяжним) під час прийняття судового рішення.

\section{References:}

1. Pchelina, O. V. (2017). Teoretychni zasady formuvannia ta realizatsii metodyky rozsliduvannia zlochyniv u sferi sluzhbovoi diialnosti [Theoretical bases of formation and realization of a technique of investigation of crimes in the sphere of official activity]: avtoreferat dysertatsiyi na zdobuttya naukovoho stupenyu doktora yurydychnykh nauk [the dissertation author's abstract on reception of a scientific degree of the doctor of legal sciences]. Kharkiv: KNUVS. [in Ukrainian].

2. Musiyenko, O. L. (2007). Teoretychni zasady rozsliduvannya shakhrajstva v suchasnykh umovakh [Theoretical principles of fraud investigation in modern conditions]: dysertatsiya na zdobuttya naukovoho stupenyu kandydata yurydychnykh nauk [the dissertation on competition of a scientific degree of the candidate of legal sciences]. Kharkiv: NUA. [in Ukrainian].

3. Kertjes, I. (1965). Taktika i psihologicheskie osnovy doprosa [Tactics and psychological foundations of interrogation]. Moscow: Juridicheskaja literatura. [in Russian].

4. Gross, G. (1930). Rukovodstvo dlja sudebnyh sledovatelej kak sistema kriminalistiki [Forensic Investigators' Guide as a Forensic System]. Moscow: Narodnij komissariat vnutrennih del RSFSR. [in Russian].

5. Konovalova ,V. E. (1999). Dopros: taktika i psihologija [Interrogation: tactics and psychology]. Harkov. [in Russian].

\footnotetext{
${ }^{1}$ Коновалова В. Е. (1999). Допрос: тактика и психология. Харьков, 73
} 